\title{
Selective control of Rhipicephalus (Boophilus) microplus in fipronil-treated cattle raised on natural pastures in Lages, State of Santa Catarina, Brazil
}

\author{
Controle seletivo do Rhipicephalus (Boophilus) microplus em bovinos criados em campo nativo, \\ no município de Lages, Santa Catarina, Brasil \\ Fernanda Paim ${ }^{1 *}$; Antonio Pereira de Souza ${ }^{1}$; Valdomiro Bellato ${ }^{1}$; Amélia Aparecida Sartor ${ }^{1}$ \\ ${ }^{1}$ Centro de Ciências Agroveterinárias - CAV, Universidade do Estado de Santa Catarina - UDESC
}

Received June 14, 2010

Accepted October 8, 2010

\begin{abstract}
An examination of a selective control of Rhipicephalus (Boophilus) microplus and consequent cost reduction was carried out in two areas of native pasture in the municipality of Lages, State of Santa Catarina, Southern Brazil, from May 2007 to April 2009. Forty cattle were divided into two groups of 20 animals each (conventional and selective control groups). At 14-day intervals female ticks larger than $4.5 \mathrm{~mm}$ found on the right flank of cattle bodies were counted, and these results multiplied by two. Fipronil $1 \mathrm{mg} \cdot \mathrm{kg}^{-1}$ pour on was then administered for tick control. In the conventional group all the cattle were treated when tick count averaged more than 40 female ticks per animal while in the selective group only animals parasitized by more than 40 ticks were treated with acaricide. Every 28 days the cattle's weight was checked for cost-effective analysis. The conventional group required an additional 20 doses of fipronil compared with the selective one. There was no statistically significant differences regarding weight gain in both groups.
\end{abstract}

Keywords: Rhipicephalus (Boophilus) microplus, cattle, fipronil, selective control, conventional control.

\section{Resumo}

Com o objetivo de avaliar o método de controle seletivo do Rhipicephalus (Boophilus) microplus e reduzir os custos para o controle, de maio de 2007 a abril de 2009, em duas invernadas de campo nativo no município de Lages, SC, utilizaram-se 40 bovinos que foram divididos em dois grupos (convencional e seletivo), de 20 animais cada. A cada 14 dias foi realizada a contagem das fêmeas maiores ou igual a $4,5 \mathrm{~mm}$, no lado direito do corpo dos animais, e o valor obtido, multiplicado por dois. Foi utilizado fipronil $1 \mathrm{mg} \cdot \mathrm{kg}^{-1}$ pour on para o controle de carrapatos. No grupo convencional, foram tratados todos os bovinos quando a média do grupo foi igual ou superior a 40 fêmeas e no grupo seletivo, foram tratados apenas os animais que apresentaram uma infestação igual ou superior a 40. A cada 28 dias foi realizada a pesagem dos animais para análise da relação custo/benefício. Foram realizadas 20 aplicaçóes a mais do carrapaticida no grupo convencional em relação ao seletivo. Náo houve diferença estatística entre o ganho de peso do grupo convencional em relação ao grupo seletivo.

Palavras-chave: Rhipicephalus (Boophilus) microplus, bovino, fipronil, controle seletivo, controle convencional.

\section{Introduction}

The State of Santa Catarina is located in Southern Brazil between the parallels $25^{\circ}$ and $29^{\circ}$ South, an area where it is found a major ectoparasite of cattle, Rhipicephalus (Boophilus) microplus. The cattle herd in Santa Catarina consists of over 3.8 million animals (IBGE, 2008) and is characterized by small properties with an average population around 23 head per property (MENDES, 2006).

\footnotetext{
*Corresponding author: Fernanda Paim

Mestrado em Ciência Animal, Centro de Ciências Agroveterinárias - CAV, Universidade do Estado de Santa Catarina - UDESC,

Rua Senador Salgado Filho, 282, CEP 88523-150, Coral, Lages - SC, Brazil;

e-mail: fernandapaim@yahoo.com.br; Bolsista CAPES/2009
}

The favorability index for the development of $R$. (B.) microplus in the city of Lages (28) where the experiment was conducted is one of the lowest in the state (HONER et al., 1993), but livestock in the region is affected by tick damage.

Economic losses result from the transmission of babesiosis and anaplasmosis pathogens to cattle causing decrease in weight gain, reduced milk production, low quality of leather, potential loss due to mortality, as well as increased costs of treatment and workmanship. Grisi et al. (2002) estimated that losses caused by Boophilus microplus in Brazil considering both direct and indirect damage may exceed two billion dollars per year. 
Cattle raisers seeking to increase productivity have implemented technologies of pasture cultivation and/or improvement of native pasture, enhancing cattle production and increasing the number of heads, which have contributed to greater infestations. There is an intensification of the system used, especially increased use of chemicals for parasite control in cattle herds with increasing selection pressure, which may result in the emergence of parasites resistant to the chemicals used.

According to Martins (2006), despite selection of more resistant breeds of cattle, rotational grazing management systems and immunization of cattle against ticks, the use of chemical acaricides is still necessary as it remains the most effective method for tick control. Any control method including chemicals is likely to be used excessively and may increase the risk of environment contamination and emergence of resistant strains (SANTOS JÚNIOR; FURLONG; DAEMON, 2000). According to Vieira et al. (2003), the use of strategic control can lead to a sharp fall in the population of $R$. (B.) microplus, causing enzootic instability for bovine babesiosis.

In order to reduce factors contributing to the occurrence of parasites resistant to antiparasitic drugs, and to minimize treatment costs, partial control of the flock, also known as selective control, has been investigated since that, in a parasite population, only few animals have high concentrations of parasites (MADALENA et al. 1985). And these animals are the target of selective control.
Souza et al. (2005) reported the efficacy of selective treatment in reducing the number of Haematobia irritans (89.35\%). It also possibly offers the advantage of delaying the development of resistance due to the presence of a refugee population that is crossed with the population exposed to the chemicals applied. Martins et al. (2002), in an experiment with European cattle in Rio Grande do Sul, examined a form of partial treatment. Half of the flock received strategic treatment and the other did not receive any acaricide. The strategically treated group was found to have, at certain times, large amounts of $R$. (B.) microplus and the group who did not receive any treatment showed very high levels of infestation, resulting in an abundant source of larvae on pasture, re-infesting both groups.

The objective of the present study was to examine the selective control method of $R$. (B.) microplus and consequent cost reduction.

\section{Material and Methods}

The experiment was conducted from May 2007 to April 2009 in a farm located $25 \mathrm{~km}$ from Lages, Southern Brazil (27 49' 611” S and $50^{\circ} 32^{\prime} 303^{\prime \prime} \mathrm{W}$ and altitude of $927 \mathrm{~m}$ ).

A total of 40 Charolais cross cattle aged around one year at the start of the experiment were divided into two groups of

Table 1. Average infestation rate, number of cattle infested with more than 40 females of Rhipicephalus (Boophilus) microplus larger than $4.5 \mathrm{~mm}$ and number of treatments applied from May 2007 to April 2008, Lages, Southern Brazil.

\begin{tabular}{|c|c|c|c|c|c|c|c|}
\hline \multirow[t]{2}{*}{ Month/ year } & \multirow{2}{*}{$\begin{array}{l}\text { Count/ } \\
\text { month }\end{array}$} & \multicolumn{3}{|c|}{ Conventional control group } & \multicolumn{3}{|c|}{ Selective control group } \\
\hline & & Avg. N. females & N. of animals & N. of treatments & Avg. N. females & N. of animals & N. of treatments \\
\hline \multirow[t]{2}{*}{ May/07 } & $1^{\mathrm{st}}$ & 20.9 & 3 & 0 & 18.2 & 3 & 3 \\
\hline & $2^{\text {nd }}$ & 5.3 & 1 & 0 & 3.4 & 0 & 0 \\
\hline June/07 & $1^{\text {st }}$ & 2.8 & 1 & 0 & 3.1 & 0 & 0 \\
\hline \multirow[t]{2}{*}{ July/07 } & $1^{\text {st }}$ & 20.8 & 3 & 0 & 4.8 & 1 & 1 \\
\hline & $2^{\text {nd }}$ & 25.3 & 4 & 0 & 0.1 & 0 & 0 \\
\hline \multirow[t]{3}{*}{ September/07 } & $1^{\text {st }}$ & 0.0 & 0 & 0 & 0.3 & 0 & 0 \\
\hline & $2^{\text {nd }}$ & 0.4 & 0 & 0 & 4.8 & 0 & 0 \\
\hline & $3^{\text {rd }}$ & 2.5 & 0 & 0 & 2.0 & 0 & 0 \\
\hline \multirow[t]{2}{*}{ October/07 } & $1^{\text {st }}$ & 0.9 & 0 & 0 & 1.2 & 0 & 0 \\
\hline & $2^{\text {nd }}$ & 13.5 & 3 & 0 & 12.2 & 0 & 0 \\
\hline \multirow[t]{2}{*}{ January/08 } & $1^{\mathrm{st}}$ & 1.4 & 0 & 0 & 6.3 & 1 & 1 \\
\hline & $2^{\text {nd }}$ & 65.9 & 11 & 20 & 58.6 & 14 & 14 \\
\hline \multirow[t]{3}{*}{ February/08 } & $1^{\text {st }}$ & 0.8 & 0 & 0 & 0.8 & 0 & 0 \\
\hline & $2^{\text {nd }}$ & 0.3 & 0 & 0 & 2.8 & 1 & 1 \\
\hline & $3^{\text {rd }}$ & 10.8 & 1 & 0 & 20.4 & 0 & 0 \\
\hline \multirow[t]{2}{*}{ March/08 } & $1^{\text {st }}$ & 121.3 & 17 & 20 & 24.7 & 5 & 5 \\
\hline & $2^{\text {nd }}$ & 2.3 & 0 & 0 & 1.2 & 0 & 0 \\
\hline \multirow[t]{2}{*}{ April/08 } & $1^{\text {st }}$ & 0.4 & 0 & 0 & 28.0 & 3 & 3 \\
\hline & $2^{\text {nd }}$ & 37.5 & 6 & 0 & 174.9 & 16 & 16 \\
\hline
\end{tabular}


20 animals. They were randomized according to their degree of $R$. (B.) microplus infestation and housed in two paddocks of pasture naturally infested by $R$. (B.) microplus, while respecting the capacity of 0.4 cattle.ha ${ }^{-1}$.

In April 2007, after the animals were grouped and before the beginning of the experiment, all animals with parasitic infection by helminths of the order Strongylida greater than 250 eggs per gram (EPG) were treated with anthelmintic albendazole sulphoxide at a dose of $5 \mathrm{mg} \cdot \mathrm{kg}^{-1}$ subcutaneously. Every 28 days the animals were weighed for cost-effective analysis.

At 14-day intervals female ticks larger than $4.5 \mathrm{~mm}$ found on the right flank of cattle bodies were counted in both groups. The number of ticks counted was multiplied by two to obtain an estimated total number of ticks per animal. In group 1, the conventional control group, all animals were treated when their average infestation was equal to or greater than 40 females. In group 2 , the selective control group, only animals with infestation lower than 40 females were treated. The insecticide used was $1 \%$ fipronil at a dose of $1 \mathrm{mg} \cdot \mathrm{kg}^{-1}$, applied to the back (pour on) of the animals. This acaricide was assessed in the field, property, at baseline, the percentage reduction in the number of ticks of $100 \%$.
Statistical analyses were conducted using data from all animals treated according to the experimental design. A linear model analysis of variance with measures repeated in time was performed. All analyses were conducted using SAS ${ }^{\circledR}$ (SAS, 2003) MIXED procedure (LITTEL et al., 2006). The level of significance was $5 \%$ for all analyses.

\section{Results and Discussion}

During the experimental period, 200 doses of fipronil were applied in the selective control group while 220 were applied in the conventional control group (Tables 1 and 2). Two animals were excluded from the selective group during the experiment, one in January 2008 and another one in February 2009 due to health conditions that required their withdrawal from the study.

A higher number of treatments was administered to the conventional group due to high parasite load seen in some animals. The average infestation was high, which resulted in the treatment of all animals, even of those who did not necessarily require insecticide application due to low infestation on a count day. For example, during the third count of January 2009 (Table 2),

Table 2. Average infestation rate, number of cattle infested with more than 40 females of Rhipicephalus (Boophilus) microplus larger than $4.5 \mathrm{~mm}$ and number of treatments applied from May 2008 to April 2009, Lages, Southern Brazil.

\begin{tabular}{|c|c|c|c|c|c|c|c|}
\hline \multirow[t]{2}{*}{ Month/year } & \multirow{2}{*}{$\begin{array}{l}\text { Count/ } \\
\text { month }\end{array}$} & \multicolumn{3}{|c|}{ Conventional control group } & \multicolumn{3}{|c|}{ Selective control group } \\
\hline & & Avg. N. females & N. of animals & Avg. N. females & N. of animals & Avg. N. females & N. of animals \\
\hline \multirow[t]{2}{*}{ May/08 } & $1^{\mathrm{st}}$ & 100.7 & 15 & 20 & 24.0 & 2 & 2 \\
\hline & $2^{\text {nd }}$ & 8.5 & 1 & 0 & 5.8 & 0 & 0 \\
\hline \multirow[t]{2}{*}{ June/08 } & $1^{\mathrm{st}}$ & 3.0 & 0 & 0 & 28.2 & 4 & 4 \\
\hline & $2^{\text {nd }}$ & 17.2 & 2 & 0 & 89.7 & 15 & 15 \\
\hline July/08 & $1^{\mathrm{st}}$ & 60.9 & 7 & 20 & 14.3 & 1 & 1 \\
\hline \multirow[t]{3}{*}{ August/08 } & $1^{\mathrm{st}}$ & 5.0 & 0 & 0 & 15.8 & 2 & 2 \\
\hline & $2^{\text {nd }}$ & 1.6 & 0 & 0 & 2.5 & 0 & 0 \\
\hline & $3^{\text {rd }}$ & 50.7 & 11 & 20 & 40.3 & 11 & 11 \\
\hline \multirow[t]{2}{*}{ September/08 } & $1^{\mathrm{st}}$ & 4.4 & 0 & 0 & 7.0 & 0 & 0 \\
\hline & $2^{\text {nd }}$ & 2.7 & 0 & 0 & 15.0 & 3 & 3 \\
\hline \multirow[t]{2}{*}{ December/08 } & $1^{\mathrm{st}}$ & 8.4 & 1 & 0 & 15.5 & 3 & 3 \\
\hline & $2^{\text {nd }}$ & 131.5 & 19 & 20 & 92.6 & 12 & 12 \\
\hline \multirow[t]{3}{*}{ January/09 } & $1^{\mathrm{st}}$ & 5.4 & 0 & 0 & 32.1 & 8 & 8 \\
\hline & $2^{\text {nd }}$ & 102.9 & 11 & 20 & 44.4 & 10 & 10 \\
\hline & $3^{\text {rd }}$ & 40.3 & 5 & 20 & 62.8 & 9 & 9 \\
\hline \multirow[t]{2}{*}{ February/09 } & $1^{\text {st }}$ & 7.9 & 0 & 0 & 37.3 & 7 & 7 \\
\hline & $2^{\text {nd }}$ & 14.1 & 3 & 0 & 42.1 & 6 & 6 \\
\hline \multirow[t]{2}{*}{ March/09 } & $1^{\mathrm{st}}$ & 104.4 & 12 & 20 & 47.0 & 8 & 8 \\
\hline & $2^{\text {nd }}$ & 9.9 & 1 & 0 & 69.3 & 7 & 7 \\
\hline
\end{tabular}


four animals showed a parasite load greater than 100 ticks, one of them greater than 230. Fifteen cattle had parasite loads below 40 ticks, five of them under six ticks.

In the first year of the experiment, from May to September, the selective control group had an average number of females smaller than the conventional group and a lower number of insecticide doses (four) were applied in the selective group. There was no significant selection pressure during this phase of the experiment.

The average number of females in both groups was similar over time with an increase in the number of doses used in both groups during the second year of the experiment. There was a $10 \%$ difference in the number of doses used by the end of the experimental period in both groups of animals, suggesting that selective control has a slight advantage in controlling the population of ticks compared to the conventional control method. This fact is probably due to a residual power of fipronil which reduces the remaining population of parasites. It was found that $88.07 \%$ of the animals in the selective group were treated over a 24 month period.

As for the period of greatest infestation of $R$. (B.) microplus it was observed that during the summer months the parasite load was higher with an increase in tick populations starting from the month of November in both groups. The lowest infestations were seen during the period of lower temperatures (Table 1), which corroborates the finding of a study by Souza et al. (1988a) on the seasonal variation of $R$. (B.) microplus conducted in southern Brazil. The lowest tick infestations in cattle occurred from August to November due to non-occurrence of eggs, and the largest infestations were recorded from January to April due to the occurrence of high hatching of larvae during January and February (SOUZA et al., 1988b).

The average weight of both groups at the beginning of the experiment was very similar, 174.55 and $174.15 \mathrm{~kg}$ in the selective and conventional control groups, respectively. After 24 months, their average weight was 336.94 and $323.15 \mathrm{~kg}$ respectively, with a higher average weight gain of $13.39 \mathrm{~kg}$ in the animals in the selective group, however, this difference was not statistically significant. In spite of the environmental importance due to lower use of fipronil and thereby lower costs, the small reduction in the number of doses used was not sufficient to compensate the farmers' costs with manpower for animal handling.

\section{Conclusion}

Selective control method with the use of fipronil $1 \mathrm{mg} \cdot \mathrm{kg}^{-1}$ for two years, despite a $10 \%$ reduction in insecticide applications, proved to be less cost-effective and did not show any relevant advantages compared to the conventional method for the control of Rhipicephalus (Boophilus) microplus in cattle raised on natural pastures in Lages, Southern Brazil.

\section{References}

GRISI, L. et al. Impacto econômico das principais ectoparasitoses em bovinos no Brasil. A Hora Veterinária, v. 21, n. 125, p. 8-10, 2002.

HONER, M. R. et al. Epidemiologia e Controle do Carrapato dos Bovinos Boophilus microplus no Estado de SC. Florianópolis: Epagri, 1993. 26 p. (Boletim técnico, 62).

INSTITUTO BRASILEIRO DE GEOGRAFIA E ESTATÍSTICA IBGE. Santa Catarina - Pecuária. 2008. Disponível em: <http://www. ibge.gov.br/estadosat/temas.php?sigla $=$ sc\&tema $=$ pecuaria2009>. Acesso em: 21 jan. 2010.

LITTEL, R. C. et al. SAS ${ }^{\varpi}$ for Mixed Models. $2^{\text {nd }}$ ed. Cary, NC, USA: SAS Institute Inc., 2006. 834 p.

MADALENA, F. E. et al. Causes of variation of field burdens of cattle ticks (B. microplus). Revista Brasileira de Genética, v. 8, n. 2, p. 361-375, 1985.

MARTINS, J. R. et al. Partial strategic tick control within a herd of European breed cattle in the state of Rio Grande do Sul, southern Brazil. Experimental and Applied Acarology, v. 27, n. 3, p. 241-251, 2002.

MARTINS, J. R. S. Carrapato Boophilus microplus (Can. 1887) (Acari: Ixodidae) resistente a ivermectina, moxidectina e doramectina. 2006. 74 f. Tese (Doutorado em Ciência Animal)-Escola de Veterinária, Universidade Federal de Minas Gerais Belo Horizonte, 2006.

MENDES, R. E. O impacto financeiro da rastreabilidade em sistemas de produção de bovinos no Estado de Santa Catarina, Brasil. Ciência Rural, v. 36, n. 5, p. 1524-1528, 2006.

SANTOS JÚNIOR, J. C. B.; FURLONG, J.; DAEMON, E. Controle do carrapato Boophilus microplus (Acari: Ixodidae) em sistemas de produçấo de leite da microrregião fisiográfica fluminense do Grande Rio - Rio de Janeiro. Ciência Rural, v. 30, n. 2, p. 305-311, 2000.

SAS INSTITUTE INC. SAS Ver. 9.1.3. Cary, NC, USA: SAS Institute Inc., 2003

SOUZA, A. P. et al. Variação Sazonal de Boophilus microplus no Planalto Catarinense. Pesquisa Agropecuária Brasileira, v. 23, n. 6, p. 627-630, 1988a.

SOUZA, A. P. et al. Fase de Vida livre do Boophilus microplus no Planalto Catarinense. Pesquisa Agropecuária Brasileira, v. 23, n. 4, p. 427-434, 1988 b.

SOUZA, A. P. et al. Variação Sazonal de Haematobia irritans no Planalto Catarinense e eficiência do "Controle Dirigido". Revista Brasileira de Parasitologia Veterinária, v. 14, n. 1, p. 11-15, 2005.

VIEIRA, M. I. B et al. Estratégias de controle do carrapato Boophilus microplus (Canestrini, 1887) e influência na estabilidade enzoótica da babesiose bovina. Revista Brasileira de Parasitologia Veterinária, v. 12, n. 4, p. 139-144, 2003. 